\title{
Microbial Hazards During Frying and Grilling Frozen Shrimp \\ (Panaeus spp.)
}

\author{
Nadia, A. Abd-El-Aziz ${ }^{1}$, yehia, G. Moharram ${ }^{2}$
}

\begin{abstract}
The safety hazards especially microbiological ones were examined in this study during preparing two different sizes of various frozen shrimp types for frying and grilling . The results of the statistical analysis of the data showed significance effects at $P<0.05$ for; (1) cooking method, interaction between type and sizes on weight loss ,(2)cooking method, interaction between type ,size,and cooking method on pH,(3)cooking method, interaction between type and cooking method on TVC count (4) type ,cooking method and their interaction on Enterobacteriaceae count, (5) cooking method on count of coliform and Staphylococcus aureus of frozen shrimps. E.coli did not detected in different types and sizes of frozen shrimps after thawing, marinating, breading, frying and grilling. This is an indication that microbiological hazards are primarily a reflection of the hygienic practices and condition followed during preparing and cooking of frozen shrimp. Based on the results on this research, Hazard Analysis Critical Control Points (HACCP) charts were suggested for frying and grilling frozen shrimp.
\end{abstract}

Keywords:- Saftey, Microbiological hazards, Frozen shrimp, Breading, Marinating, Frying, Grilling.

\section{INTRODUCTION}

Shrimp (Panaeus spp) is the most important seafood traded worldwide (Oosterveer, 2006). It is one of the most widely consumed aquatic products for it's high nutritious value and delicious taste. (He Wang et al., 2010).

In commercial scale, shrimp products are constrained as fresh or frozen in markets. Quality of fresh or wet shrimp decreases due to an implication of physical, chemical and microbiological forms of deterioration (Gonzalez-Fandos et al., 2005and He Wang et al, 2010). Enzymatic and chemical reactions are usually responsible of the freshness lose wherease microbial activity is the main cause for spoilage. (Gram and Huss, 1996). Cooling, removing the cephalothorax containing organs rich in an autolysis enzymes, using sodium bisulphate alone and/or with food preservates are essential to extend keeping quality of harvested shrimp (Mohamed Hatha et al., 2003 and Jeyasekaran et al., 2006). Raw shrimps may be frozen in the following types of products; whole raw frozen shrimp, headless frozen shrimp (HL), peeled or raw headless frozen shrimp without the shell (Peeled undeveined, PUD), peeled and deveined frozen shrimp (free from vein,PD),peeled deveined and split (butterfly, BT), frozen broken shrimp or pieces of shell on tail or peeled pieces. (Ian-Dor and Claus-Frimodt, 1987). Generally freezing reduces the viable count

with the number continuing to fall during frozen storage (Mohamed Hatha et al., 2003).

Different methods can be used to cook fresh and frozen shrimps; steam cooking in chest or retort for 10$15 \mathrm{~min}$. at temperature of $95-100^{\circ} \mathrm{C}$ or cooking in boiling salted water $(3 \% \mathrm{Nacl})$ or grilling in grill or oven and/or frying in hot cooking oil at $160-180^{\circ} \mathrm{C}$ for 1-3 min. after thawing, marinating and breading (Fall et al., 2012).

After cooking, cooked shrimps should be cooled rapidly to $\sim 30^{\circ} \mathrm{C}$ to avoid over cooking, sticking of meat to shell, and to keep it's natural flavour. Cooked shrimps contain $62-67 \%$ moisture, 24 to $30 \%$ protein, not less than $0.6 \%$ oil and 3.8 to $4.5 \%$ ash. (Kanduri and Eckhardt, 2002). According to Larke and Farber (1971) pasteurization the inoculated shrimp meat with Clostridium botulinum type E spore for $5 \mathrm{~min}$. at $82.5^{\circ} \mathrm{C}$ following by cooling at $4.4^{\circ} \mathrm{C}$ retarded the toxin development for 40 days. Meanwhile increasing the pasteurization temperature to $85^{\circ} \mathrm{C}$ for $3 \mathrm{~min}$. provided $12 \mathrm{D}$ cook thermal death time.

During preparation for cooking, shrimp meats can be contaminated by spoilage and pathogenic microorganisms causing illness to consumer (Norrung and Buncic, 2008). Epidemiological and microbiological studies have identified cross contamination during preparation, cooking and subsequent bacterial growth or recontamination during handling and storage of such product as the major source of food infection and/or intoxication (PatriciaAnacleto et al., 2011). Utensils, machines, food additives, workers in addition to improper hygienic, handling and cooking practices are considered an important means of cross contamination of such products (Perez-Rodriguez et al., 2010). The $\mathrm{pH}$ value, water activity, level of food additives, storage temperature and cooking condition are together not fully assurance the microbiological safety against microorganisms particularly pathogenic ones. (FDA,

${ }^{1}$ Meat and Fish Technol. Res. Dept. Food Technol.

Res. Inst. Agric. Research Center, El-Sabahia,Alexandria, Egypt.

${ }^{2}$ Food Science and Tecnology Department, Faculty of Agriculture,

Received May 5, 2016, Accepted June 16, 2016 
2003 and Garido et al., 2009). Therefore an estimation the safety hazards especially microbiological ones during preparing two different sizes of various frozen shrimp types for frying and grilling was the main aim of this research. The different hazards, control measurements, critical control points and their limits and tests as well as the suggested correction actions were identified to produce safe fried and grilled shrimp products.

\section{MATERIALS AND METHODS}

\section{Materials :}

Five kilogram samples of each of the two sizes, 4080 and 80-120 count per pound, of the following frozen shrimp products were directly obtained from one of the Egyptian imported food company through summer 2015; peeled or raw headless block frozen shrimp without shell (B. PUD), peeled deveined block frozen shrimp (free from vein. B. PD), peeled or raw headless individually quick frozen (IQF) shrimp(IQF-PUD), and peeled deveined IQF frozen shrimp(IQF-PD). The samples were transported to the laboratory in ice boxes under aseptic condition and stored immediately at $-20^{\circ} \mathrm{C}$ in deep freezer until used. The other materials included, Austrian refined iodized common salt, Asala dried spices mixture (white, red and black pepper, ginger, nutmeg, cinnamon, chili pepper and cardamom), 72\% extraction rate wheat flour, fine wheat bread crumbs, Heinz tomato paste (16-18\% dry solids), ultra high temperature (UHT) sterilized milk, Heinz vinegar with $4 \%$ acetic acid, fresh white shell hen eggs, fresh white onions, garlic and lemon fruits, Al-Nakhletein shortening, low density polyethylene (LDPE) bags were brought from local market at Alexandria City, Egypt. All chemicals and reagents used in this work were an analytical grade.

\section{Methods:}

\section{Preparation of fried and grilled shrimps:-}

Figures 1 and 2 illustrate the process flow diagrams for fried and grilled products from frozen shrimps. The first step in both products was thawing the frozen shrimps over night at $4^{\circ} \mathrm{C}$ on stainless steel screening after removing from their polyethylene bags, then washing several times with tap water and draining. In case of fried products, the drained shrimps were dressed with mixture of minced onions, garlic, spices mixture, salt and lime juice, then stored at $4^{\circ} \mathrm{C}$ for $1-3 \mathrm{hrs}$. in a refrigerator. The cooled dressed shrimps were coated first with a thin layer of $72 \%$ extraction rate wheat flour then immersed in a mixture of 3:20 w/v whole liquid eggs to sterilized liquid milk and coated with thin layer of fine ground crumbs. The resulted coated shrimps were kept at $4^{\circ} \mathrm{C}$ in a refrigerator at least for $45 \mathrm{~min}$. before deep frying in batch fryer. The cooled coated shrimps were placed in a wire mesh basket and immersed in hot shortening, $170^{\circ} \mathrm{C}$, for desired frying time, 1-3 min., then basket was pulled out, drained and the fried product was cooled, packed in LDPE bags. (Kanduri and Eckhardt, 2002 and He Wang et al., 2010). Grilled product was prepared by mixing the combined all marinade ingredients (Lemon Juice, minced garlic and onion, spices mixture, vinegars, salt, tomato paste and water) with thawed washed drained shrimp, and marinating 4-hrs under refrigeration condition, $4^{\circ} \mathrm{C}$, in a refrigerator (Sedaroglu et al., 2007). The marinated shrimps were placed in stainless steel tray and cooked in heated grid iron grill until cooked at $\sim 200^{\circ} \mathrm{C}$ for desired grilling time, 3-5 min, the end product was cooled and packed in LDPE bags.

\section{Analytical methods:-}

\section{1- Weight loss and pH:}

The loss in weight of frozen shrimps after thawing, frying and grilling was calculated as percentage as described by Kanduri and Eckhardt (2002).

The $\mathrm{pH}$ of thawed and marinated shrimps was determined using Testo $\mathrm{pH}$ meter,( type 230, Lenzkirch, Germany) at room temperature $\left(25 \pm 3^{\circ} \mathrm{C}\right)$ after mixing $10 \mathrm{~g}$. of homogenized sample in $100 \mathrm{ml}$ of distilled water as mentioned in AOAC methods (AOAC, 2000).

\section{2- Microbiological analysis:}

Samples of thawed, marinated, breaded, fried and grilled shrimp muscles were cut to very small pieces using sterile knife and forceps then $10 \mathrm{~g}$. of each sample was homogenized using $90 \mathrm{ml}$. sterile physiological saline $(0.85 \%)$ solution and serial decimal dilutions $\left(10^{1}\right.$ to $10^{9}$ ) of each homogenate were prepared using the diluents for the respective microbiological analysis (Downes and Ito, 2001). Appropriate dilutions were used for enumeration using standard microbiological pour plate technique and recommended culture media of Oxoid (2002). Plate count agar medium was used for enumerating the Total Viable Count (TVC) after incubating at $35-37^{\circ} \mathrm{C}$ for $48 \mathrm{hrs}$. Violet red bile agar with methyl umbeliferyl glucouronide (VRB-MUG) selective media was used to isolate coliform, gram negative enteric bacteria and rapid detection of $E$. coli. The prepared dilution of frozen shrimp products homogenate was inoculated in sterile Petri dishes then medium was poured and plates were incubated at $37{ }^{\circ} \mathrm{C}$ for 18-24 hrs.

Colonies of lactose negative Enterobacteriaceae are colorless and those of lactose positive are red and often surround by a forbid zone due to precipitation of bile acids meanwhile light blue fluorescent colonies under UV-lamp (336nm) denote as E. coli. 
Receiving of frozen shrimp<smiles>[3H]C</smiles>

Thawing at $4^{\circ} \mathrm{C}$ over night in a refrigerator<smiles>CCC</smiles>

Dressing in mixture of minced onions, minced garlic, spices mixture salt and lime juice then keeping

at $4^{\circ} \mathrm{C}$ for 1-3 hrs in refrigerator.

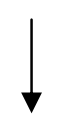

Coating with a thin layer of $72 \%$ extraction wheat flour, immersing in a mixture of 3:20 W/ $\mathrm{V}$ whole liquid egg to sterilized liquid milk Following by coating with a thin layer of fine ground bread crumbs at $4^{\circ} \mathrm{C}$ for $1-3 \mathrm{hrs}$ in refrigerato

Keeping at $4^{\circ} \mathrm{C}$ for $45 \mathrm{~min}$

Frying at $170^{\circ} \mathrm{C}$ for $1-3 \mathrm{~min}$ in bath fryer

Serving or cooling

Packaging in LDPE bags

Fig. 1. Process flow diagram for fried shrimp. 


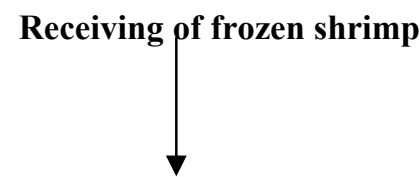

Thawing at $4^{\circ} \mathrm{C}$ for over night

Whashing with tap water

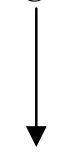

Marinating for $4 \mathrm{hrs}$ at $4^{\circ} \mathrm{C}$

Water,tomato paste,dried spices mixture

squeezed lime juice,minced

Garlic,onion,vinegar,salt

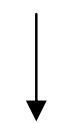

Grilling at $200{ }^{\circ} \mathrm{C}$ for $3-5 \mathrm{~min}$.

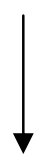

Serving or cooling

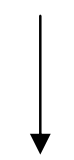

Packaging in LDPE bags

Fig. 2. Process flow diagram for grilled shrimp 
The recommended Difico Barid parker agar medium by ICMSF (1978) was used to detect coagulase active Staphylococcus aureus after incubating the plates at 35$37^{\circ} \mathrm{C}$ for $48 \mathrm{hrs}$. The black shiny colonies with narrow white margin and surrounded by clear zones were counted as Staphylococcus aureus.

\section{3- Statistical analysis:}

The data of the effects of the following factors, product type, size, cooking method of shrimp as well as their interactions on microbiological hazards, weight loss and $\mathrm{pH}$ were statistically analysed by ANOVA and differences among mean values were processed by LSD test using SAS (Release. 9, SAS Institute, NC, USA). Mean values were reported and significance was defined at $\mathrm{P}>0.05$.

\section{ESULTS AND DISCUSSION}

Tables (1) to (6) show the weight loss, $\mathrm{pH}$, counts of TVC, Enterobacteriaceae, coliform, and Staphylococcus aureus of frozen shrimps after thawing and during cooking by frying and grilling processes. The results of the statistical analysis of the data in these tables indicated that there were significance effects at $\mathrm{P}>0.05$ for cooking method, interaction between type and size on weight loss, cooking method, interaction between type, size and cooking method on $\mathrm{pH}$, cooking method, interaction between type and cooking method on TVC count, type, cooking method and their interaction on Enterobacteriaceae count, cooking method on count of both coliform and Staphylococcus aureus of shrimp. This means that the general characteristics and microbiological quality of cooked products were based mainly on cooking method, following by type and size of frozen shrimp. According to Valdimarsson et al. (1998) cooked shrimp could represent a serious health problem or an economic threat if not cooked under stringent conditions and control. The microbiological quality of cooked shrimp is primarily a reflection of the hygienic condition in the processing plants, kitchens, and/or restaurants as the initial heat treatment reduces the bacterial load to very low level.

\section{1- Weight loss and pH:}

Results in Table (1) show the weight loss of frozen shrimp types after thawing, frying and grilling. Grilling caused the highest significance weight loss $(\sim 19 \%)$ in different shrimp types followed by frying $(\sim 13 \%)$ and lastly thawing $(\sim 1.2 \%)$,respectively. The conditions of heat treatment, temperature and time, of each of the previous cooking methods were mostly responsible of such losses. During frying shrimps lose moisture, volatile maters and absorb oil. Meanwhile, the main weight loss of shrimps during grilling is due to moisture loss. Kanduri and Eckhardt (2002) stated that the yield of cooked shrimp meat ranged from 18.5 to $35 \%$ according to cooking method and shrimp type. Low weight loss of shrimp after thawing is mostly due to the separated drips from the frozen products. Low formed weight drip usually indicate to the good quality of shrimps before freezing and the using proper practices during freezing process. In other side, slight differences were noticed in weight loss due to size (40-80 or $80-120$ count per pound), product type (PUD or PD), freezing method (Block or IQF) of frozen shrimps during thawing, frying and grilling. Ian-Dor and Claus-Frimodt (1987). Stated that frozen peeled deveined shrimp product has long shelf life than frozen peeled undeveined one.

The $\mathrm{pH}$ value of thawed and marinated shrimps was above 7, Table (2). These results agree with those mentioned by Chen et al. (1990) and Jeyasekaran et al. (2006) for fresh and iced shrimps. The $\mathrm{pH}$ range in this study varied from 7.39 to 7.76 in thawed frozen shrimps and from 7.01 to 7.35 in marinated one. Using vinegar, lime juice and tomato paste during marinating step were behind the significance reduction of $\mathrm{pH}$ of marinated shrimp than thawed one. In contrast, slight effect was noticed for size, type and freezing method on $\mathrm{pH}$ of shrimps.

\section{2- Microbiological quality:}

It is know that food can contaminate by a variety of microorganisms during handling and processing from equipments in addition to environment such as water, air, dust, soil, ... etc. Both an intrinsic factors of food and an extrinsic factors of storage and processing conditions dictate the types of microorganisms that dominate the microflora (Moharram and Al -Kodaly, 2015).

\section{1- Total Viable Count (TVC):}

The TVC of frozen shrimp products after thawing, marinating, breading, frying and grilling were present in Table (3).

\section{The data in this table showed that:}

1- The TVC count of the thawed shrimp products range from $6.3 \times 10^{4}$ to $6.06 \times 10^{5}$. This count was compliance with the allowable limit in The Egyptian Organization for Standardization and Quality Control for shrimp (2005). It was relatively higher in thawed block frozen than IQF frozen ones, and in small size shrimps than large one as well as PUD products than PD ones, respectively. Miget (1991) stated that freezing lowered, large count of mesophilic microorganisms of shrimp due to their cold 
sensitivity. Results of Singh et al. (1987) showed that aerobic plate count (APC) at $35^{\circ} \mathrm{C}$ for shell on and peeled deveined fresh water frozen shrimps was $89 \times 10^{4}$ and $43 \times 10^{4} \mathrm{cfu} / \mathrm{g}$., respectively. This count was $31 \times 10^{4}$ and $41 \times 10^{4}$ in shell on and peeled deveined sea water frozen shrimp respectively.

2- Marinating process led to slight non significance reduction in TVC count of thawed shrimps. Such reduction was relatively clear in thawed IQF frozen large size PD shrimp products than thawed blocked frozen small size PUD product ones. Fall et al. (2012) reported that sea food products permit the development of wide range of microorganisms due to their physico-chemical properties (neutral $\mathrm{pH}$ and high content of small nitrogenous compounds). The growth of the unwanted bacteria leads to food spoilage. Generally the non significance changes in TVC count during marinating process may due to their short time at $4^{\circ} \mathrm{C}, 4 \mathrm{hrs}$, before grilling.

3- Breading of shrimp before frying caused a significance reduction in TVC count. This may be due to the combination of the natural antimicrobial effects of the raw materials such as onion, garlic, lime juice and salt used during dressing in addition to coating materials which able to the lower from shrimp free water as well as the low temperature $4^{\circ} \mathrm{C}$ used to keep both dressed and dressed coated products before frying. Among the frozen shrimp types and sizes, the reduction in TVC count was slightly observed in large size PD blocked thawed frozen shrimps than small size PUD especially IQF thawed ones.

Table 1. Weight loss of frozen shrimp after thawing, frying and grilling

\begin{tabular}{|c|c|c|c|c|c|}
\hline \multirow{2}{*}{$\begin{array}{l}\text { Frozen shrimp } \\
\text { type }\end{array}$} & \multirow{2}{*}{$\begin{array}{l}\text { Shrimp size as } \\
\text { count per pound }\end{array}$} & \multicolumn{3}{|c|}{$\%$ of weight loss \pm SD after } & \multirow{2}{*}{$\begin{array}{l}\text { Total mean } \\
\text { of weight loss }\end{array}$} \\
\hline & & Thawing & Frying & Grilling & \\
\hline \multirow{3}{*}{$\begin{array}{l}\text { Block peeled } \\
\text { undeveined }\end{array}$} & $40-80$ & $1.34 \pm 1.207$ & $13.1 \pm 3.564$ & $19.66 \pm 3.654$ & \\
\hline & $80-120$ & $1.61 \pm 0.759$ & $12.4 \pm 1.019$ & $21.4 \pm 3.261$ & \\
\hline & & & & & $\left(11.91^{\mathrm{a}}\right)$ \\
\hline \multirow{3}{*}{$\begin{array}{l}\text { Block peeled } \\
\text { deveined }\end{array}$} & $40-80$ & $1.06 \pm 0.744$ & $11.16 \pm 2.137$ & $19.24 \pm 1.357$ & \\
\hline & $80-120$ & $1.24 \pm 0.569$ & $13.12 \pm 1.165$ & $19.98 \pm 0.620$ & \\
\hline & & & & & $\left(10.96^{\mathrm{a}}\right)$ \\
\hline \multirow{3}{*}{$\begin{array}{l}\text { IQF peeled } \\
\text { undeveined }\end{array}$} & $40-80$ & $1.16 \pm 0.624$ & $13.68 \pm 0.854$ & $18.5 \pm 0.862$ & \\
\hline & $80-120$ & $0.66 \pm 0.484$ & $11.33 \pm 2.078$ & $18.78 \pm 0.953$ & \\
\hline & & & & & $\left(10.68^{\mathrm{a}}\right)$ \\
\hline \multirow{3}{*}{$\begin{array}{l}\text { IQF peeled } \\
\text { deveined }\end{array}$} & $40-80$ & $0.68 \pm 0.515$ & $12.26 \pm 1.352$ & $17.4 \pm 1.560$ & \\
\hline & $80-120$ & $1.26 \pm 0.733$ & $11.02 \pm 0.469$ & $16.76 \pm 0.671$ & \\
\hline & & & & & $\left(9.89^{a}\right)$ \\
\hline \multicolumn{2}{|c|}{ Total mean of weight loss } & $\left(1.12^{\mathrm{c}}\right)$ & $\left(12.50^{\mathrm{b}}\right)$ & $\left(18.96^{\mathrm{a}}\right)$ & \\
\hline
\end{tabular}

LSD of $\mathrm{pH}$ at $\mathrm{P}>0.05$ for :- Shrimp processing $=0.6982$, Shrimp size $=0.5087$, Shrimp type $=1.7641$

Table 2. pH of frozen shrimp after thawing and marinating

\begin{tabular}{|c|c|c|c|c|}
\hline \multirow[t]{2}{*}{ Frozen shrimp type } & \multirow{2}{*}{$\begin{array}{l}\text { Shrimp size as } \\
\text { count per pound }\end{array}$} & \multicolumn{2}{|c|}{ pH \pm SD Value after,:- } & \multirow[t]{2}{*}{ Total mean of $\mathrm{pH}$} \\
\hline & & Thawing & Marinating & \\
\hline \multirow[t]{3}{*}{ Block peeled undeveined } & $40-80$ & $7.63 \pm 1.253$ & $7.22 \pm 0.115$ & \\
\hline & $80-120$ & $7.50 \pm 0.103$ & $7.07 \pm 0.146$ & \\
\hline & & & & $\left(7.35^{\mathrm{a}}\right)$ \\
\hline \multirow[t]{3}{*}{ Block peeled deveined } & $40-80$ & $7.76 \pm 0.161$ & $7.35 \pm 0.159$ & \\
\hline & $80-120$ & $7.55 \pm 0.088$ & $7.19 \pm 0.094$ & \\
\hline & & & & $\left(7.46^{\mathrm{a}}\right)$ \\
\hline \multirow[t]{3}{*}{ IQF peeled undeveined } & $40-80$ & $7.66 \pm 0.167$ & $7.21 \pm 0.171$ & \\
\hline & $80-120$ & $7.58 \pm 0.0791$ & $7.21 \pm 0.0120$ & \\
\hline & & & & $\left(7.41^{a}\right)$ \\
\hline \multirow[t]{3}{*}{ IQF peeled deveined } & $40-80$ & $7.93 \pm 0.159$ & $7.01 \pm 0.137$ & \\
\hline & $80-120$ & $7.59 \pm 0.283$ & $7.23 \pm 0.310$ & \\
\hline & & & & $\left(7.30^{\mathrm{a}}\right)$ \\
\hline Total mean of $\mathrm{pH}$ & & $7.58^{\mathrm{a}}$ & $7.18^{\mathrm{b}}$ & \\
\hline
\end{tabular}




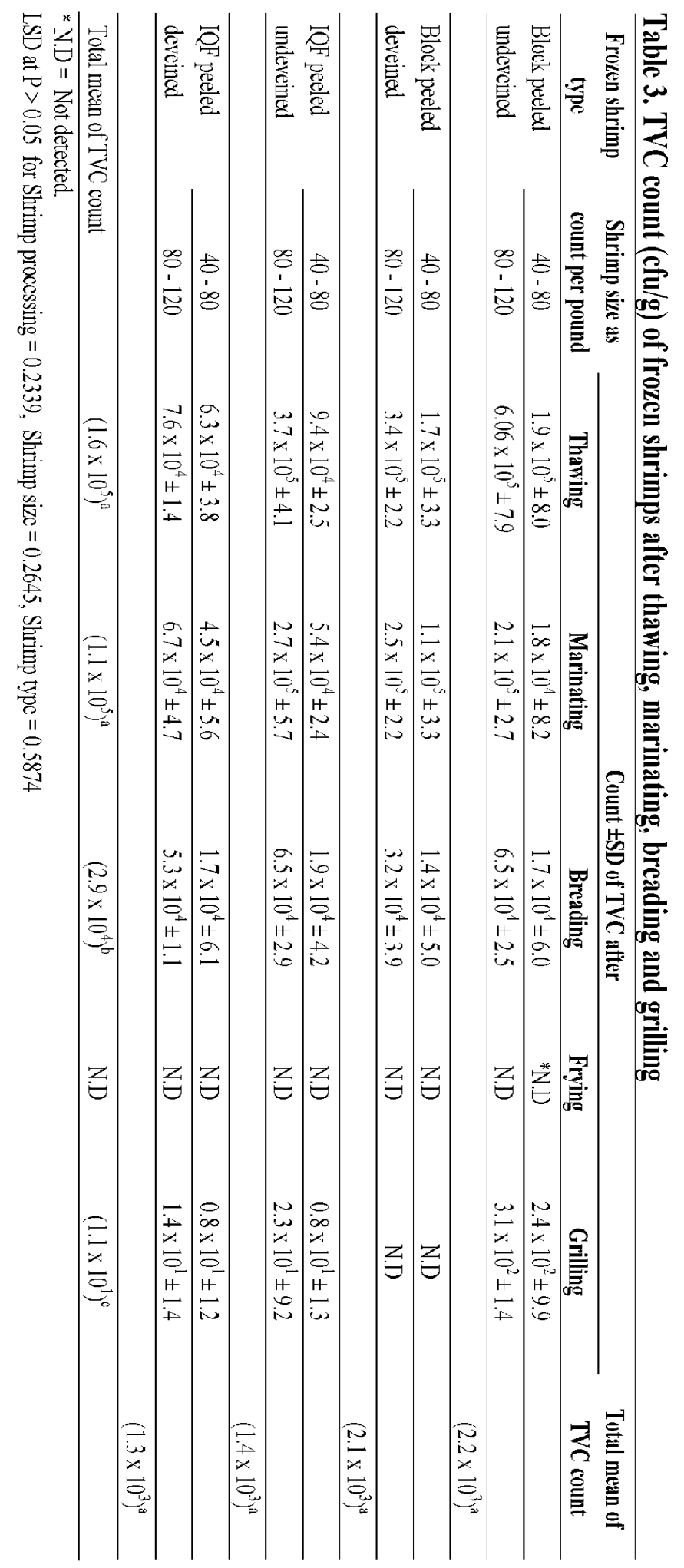


4- Heating treatment used during frying and grilling of shrimps caused nearly complete disappearing of TVC. No detection of TVC was recorded in all types of fried shrimps whereas few numbers were detected in small and large size of PUD blocked frozen (2.4$\left.3.1 \times 10^{2}\right)$, both PUD and PD- IQF frozen shrimps $\left(0.8 \times 10^{1}\right.$ to $\left.2.3 \times 10^{1}\right)$ after grilling. Such counts are very low than those reported by Singh et al. (1987) and Mohamed Hetha et al.(2003). According to Singh et al. (1987) the count of APC at $35^{\circ} \mathrm{C}$ of shrimps was $7 \times 10^{3}$. While Mohamed Hatha et al .(2003) showed that non of 928 of the cooked peeled and deveined tail-on shrimp samples exceeded the APC of $10^{5} \mathrm{cfu} / \mathrm{g}$. The $\operatorname{ICMSF}(1986)$ has recommended $10^{6} \mathrm{~g}^{-1}$ for APC as one of microbiological specifications for cooked shrimps.

\section{Enterobacteriaceae, Coliform and $E$. coli:}

Data in Tables (4) and (5) show the very low detected count of both Enterobacteriaceae and coliform bacteria in thawed, marinated and breaded frozen shrimps. Most reports in natural flora of wild caught shrimp verify the general absence of such types of microorganisms (Miget, 1991). Presence of them especially in low load indicate the defect in an application of sanitary condition during handling and processing of frozen shrimp. The count of Enterobacteriaceae $(\mathrm{cfu} / \mathrm{g})$ was varied from $1.2 \times 10^{1}$ to
$3.4 \times 10^{3}, 1.1 \times 10^{1}$ to $1.2 \times 10^{3}$ and $1 \times 10^{1}$ to $6.4 \times 10^{2}$ in thawed, marinated and breaded frozen shrimps, respectively. Such counts are lower than that recommended $\left(10^{2}\right)$, in The Egyptian Organization for Standardization and Quality Control for Shrimp (2005). In the other side, the range of coliform load was differed from 0.3 to $2.9 \times 10^{1}, 0.3$ to $2.7 \times 10^{1}$ and 0.25 to $0.92 \times 10^{1} \mathrm{cfu} / \mathrm{g}$. in thawed, marinated and breaded frozen shrimp products particularly small size ones. Also breading process had more effect in reducing both type of bacteria than thawing and marinating steps. After frying and grilling both type of bacteria were completely disappeared as shown from Tables (4) and (5).

E.coli did not detect and absence in all analysed samples of different types, sizes, thawed, marinated, breaded, fried and grilled frozen shrimps. This agree with that mentioned in The Egyptian Organization for Standardization and Quality Control for shrimp (2005). Singh et al. (1987) found that cooked shrimps had $7 \mathrm{x}$ $10^{3}, 4$ and $3 \mathrm{cfu} / \mathrm{g}$. count of APC, coliform, and E. coli. , respectively. Generally, the presence of these three types of bacteria is an indicator of an integrity of application the good hygienic and manufacturing practices during preparing frozen shrimp for cooking.

Table 4. Enterobacteriaceae count (cfu/g) of frozen shrimps after thawing, marinating, breading, frying, and grilling

\begin{tabular}{|c|c|c|c|c|c|c|c|}
\hline \multirow{2}{*}{$\begin{array}{c}\text { Frozen } \\
\text { shrimp type }\end{array}$} & \multirow[b]{2}{*}{$\begin{array}{c}\text { Shrimp } \\
\text { size as } \\
\text { count } \\
\text { per } \\
\text { pound }\end{array}$} & \multicolumn{5}{|c|}{ Count \pm SD of Enterobacteriaceae after,:- } & \multirow{2}{*}{$\begin{array}{c}\text { Total mean } \\
\text { of TVC } \\
\text { count }\end{array}$} \\
\hline & & Thawing & Marinating & Breading & $\begin{array}{c}\text { Fryin } \\
\text { g }\end{array}$ & Grilling & \\
\hline \multirow{3}{*}{$\begin{array}{l}\text { Block peeled } \\
\text { undeveined }\end{array}$} & $40-80$ & $6.5 \times 10^{2} \pm 6.2$ & $1.2 \times 10^{3} \pm 6.4$ & $4.9 \times 10^{2} \pm 3.5$ & $*$ N.D & N..D & \\
\hline & $80-120$ & $4.3 \times 10^{3} \pm 2.3$ & $1.2 \times 10^{3} \pm 2.4$ & $6.4 \times 10^{2} \pm 1.4$ & N.D & N..D & \\
\hline & & & & & & & $\left(7.1 \times 10^{3}\right)^{\mathrm{a}}$ \\
\hline \multirow{3}{*}{$\begin{array}{l}\text { Block peeled } \\
\text { deveined }\end{array}$} & $40-80$ & $1.2 \times 10^{1} \pm 1.3$ & $1.1 \times 10^{1} \pm 1.8$ & $1.0 \times 10^{1} \pm 1.6$ & N.D & N..D & \\
\hline & $80-120$ & $1.8 \times 10^{1} \pm 1.6$ & $1.1 \times 10^{1} \pm 1.9$ & $1.0 \times 10^{1} \pm 1.7$ & N.D & N..D & \\
\hline & & & & & & & $\left(0.4 \times 10^{1}\right)^{\mathrm{b}}$ \\
\hline \multirow{3}{*}{$\begin{array}{l}\text { IQF peeled } \\
\text { undeveined }\end{array}$} & $40-80$ & $9.6 \times 10^{2} \pm 3.6$ & $8.1 \times 10^{2} \pm 3.5$ & $4.6 \times 10^{2} \pm 2.9$ & N.D & N.D & \\
\hline & $80-120$ & $1.4 \times 10^{3} \pm 2.9$ & $8.9 \times 10^{2} \pm 2.7$ & $5.7 \times 10^{2} \pm 2.8$ & N.D & N..D & \\
\hline & & & & & & & $\left(5.8 \times 10^{1}\right)^{\mathrm{a}}$ \\
\hline \multirow{3}{*}{$\begin{array}{l}\text { IQF peeled } \\
\text { deveined }\end{array}$} & $40-80$ & $1.4 \times 10^{1} \pm 2.5$ & $1.3 \times 10^{1} \pm 2.3$ & $1.0 \times 10^{1} \pm 1.9$ & N.D & N..D & \\
\hline & $80-120$ & $1.8 \times 10^{1} \pm 3.6$ & $1.6 \times 10^{1} \pm 3.3$ & $1.0 \times 10^{1} \pm 1.9$ & N.D & N..D & \\
\hline & & & & & & & $\left(0.5 \times 10^{1}\right)^{b}$ \\
\hline Total mean & Enter. & $\left(1.8 \times 10^{2}\right)^{\mathrm{a}}$ & $\left(1.2 \times 10^{2}\right)^{\mathrm{ab}}$ & $\left(7.3 \times 10^{1}\right)^{b}$ & N.D & N.D & \\
\hline
\end{tabular}

$*$ N.D $=$ Not detected.

LSD at $\mathrm{P}>0.05$ for Shrimp processing $=0.2840$, Shrimp size $=0.5763$, Shrimp type $=0.4748$ 
Table 5. Coliform count (cfu/g) of frozen shrimps after thawing, marinating, breading and grilling

\begin{tabular}{|c|c|c|c|c|c|c|c|}
\hline \multirow{2}{*}{$\begin{array}{c}\text { Frozen } \\
\text { shrimp type }\end{array}$} & \multirow{2}{*}{$\begin{array}{c}\text { Shrimp size } \\
\text { as count } \\
\text { per pound }\end{array}$} & \multicolumn{5}{|c|}{ Count \pm SD of coliform after,:- } & \multirow{2}{*}{$\begin{array}{c}\text { Total mean } \\
\text { count of } \\
\text { coliform }\end{array}$} \\
\hline & & Thawing & Marinating & Breading & $\begin{array}{c}\text { Fryin } \\
\text { g }\end{array}$ & Grilling & \\
\hline \multirow{3}{*}{$\begin{array}{l}\text { Block peeled } \\
\text { undeveined }\end{array}$} & $40-80$ & $0.9 \times 10^{1} \pm 1.6$ & $0.3 \times 10^{1} \pm 0.99$ & $0.25 \times 10^{1} \pm 0.65$ & $*$ N.D & N..D & \\
\hline & $80-120$ & $1.4 \times 10^{1} \pm 1.6$ & $0.3 \times 10^{1} \pm 0.95$ & $0.3 \times 10^{1} \pm 0.83$ & N.D & N..D & \\
\hline & & & & & & & $\left(0.3 \times 10^{1}\right)^{\mathrm{a}}$ \\
\hline \multirow{3}{*}{$\begin{array}{l}\text { Block peeled } \\
\text { deveined }\end{array}$} & $40-80$ & $1.0 \times 10^{1} \pm 1.7$ & $0.95 \times 10^{1} \pm 0.88$ & $0.9 \times 10^{1} \pm 3.9$ & N.D & N..D & \\
\hline & $80-120$ & $1.0 \times 10^{1} \pm 1.7$ & $1.0 \times 10^{1} \pm 0.16$ & $0.9 \times 10^{1} \pm 1.5$ & N.D & N..D & \\
\hline & & & & & & & $\left(0.35 \times 10^{1}\right)^{\mathrm{a}}$ \\
\hline \multirow{3}{*}{$\begin{array}{l}\text { IQF peeled } \\
\text { undeveined }\end{array}$} & $40-80$ & $1.2 \times 10^{1} \pm 2.0$ & $1.0 \times 10^{1} \pm 0.17$ & $0.8 \times 10^{1} \pm 1.5$ & N.D & N..D & \\
\hline & $80-120$ & $2.9 \times 10^{1} \pm 1.6$ & $2.7 \times 10^{1} \pm 1.5$ & $0.92 \times 10^{1} \pm 0.9$ & N.D & N..D & \\
\hline & & & & & & & $\left(0.5 \times 10^{1}\right)^{\mathrm{a}}$ \\
\hline \multirow{3}{*}{$\begin{array}{l}\text { IQF peeled } \\
\text { deveined }\end{array}$} & $40-80$ & $0.3 \times 10^{1} \pm 0.86$ & $0.3 \times 10^{1} \pm 0.83$ & $0.3 \times 10^{1} \pm 0.83$ & N.D & N..D & \\
\hline & $80-120$ & $0.9 \times 10^{1} \pm 5.1$ & $0.9 \times 10^{1} \pm 1.4$ & $0.3 \times 10^{1} \pm 1.4$ & N.D & N..D & \\
\hline & & & & & & & $\left(0.3 \times 10^{1}\right)^{\mathrm{a}}$ \\
\hline \multicolumn{2}{|c|}{ Total mean count of coliform } & $\left(1.0 \times 10^{1}\right)^{\mathrm{a}}$ & $\left(0.75 \times 10^{1}\right)^{\mathrm{a}}$ & $\left(5.5 \times 10^{1}\right)^{\mathrm{a}}$ & N.D & N.D & \\
\hline
\end{tabular}

$*$ N.D $=$ Not detected.

LSD at $\mathrm{P}>0.05$ for:- Shrimp processing $=0.3188$, Shrimp size $=0.5439$, Shrimp type $=0.6884$

Table 6. Staphylococcus aureus count (cfu/g) of frozen shrimps after thawing, marinating, breading, frying and grilling

\begin{tabular}{|c|c|c|c|c|c|c|c|}
\hline \multirow{2}{*}{$\begin{array}{c}\text { Frozen } \\
\text { shrimp type }\end{array}$} & \multirow{2}{*}{$\begin{array}{c}\text { Shrimp size as } \\
\text { count per } \\
\text { pound }\end{array}$} & \multicolumn{5}{|c|}{ Count \pm SD of $S$. aureus after,:- } & \multirow{2}{*}{$\begin{array}{c}\text { Total mean } \\
\text { count of } \\
\underline{\text { S.aureus }} \\
\end{array}$} \\
\hline & & Thawing & Marinating & Breading & Frying & Grilling & \\
\hline \multirow{3}{*}{$\begin{array}{l}\text { Block peeled } \\
\text { undeveined }\end{array}$} & $40-80$ & N.D & N.D & N.D & $*$ N.D & N..D & \\
\hline & $80-120$ & $6.9 \times 10^{1} \pm 8.7$ & $2.8 \times 10^{1} \pm 1.5$ & $3.1 \times 10^{1} \pm 1.6$ & N.D & N..D & \\
\hline & & & & & & & $\left(0.3 \times 10^{1}\right)^{\mathrm{a}}$ \\
\hline \multirow{3}{*}{$\begin{array}{l}\text { Block peeled } \\
\text { deveined }\end{array}$} & $40-80$ & $1.0 \times 10^{1} \pm 1.8$ & $0.97 \times 10^{1} \pm 1.6$ & $0.9 \times 10^{1} \pm 1.5$ & N.D & N..D & \\
\hline & $80-120$ & $3.0 \times 10^{1} \pm 1.6$ & $2.9 \times 10^{1} \pm 1.4$ & $2.5 \times 10^{1} \pm 1.4$ & N.D & N..D & \\
\hline & & & & & & & $\begin{array}{c}(0.55 \mathrm{x} \\
\left.10^{1}\right)^{\mathrm{a}} \\
\end{array}$ \\
\hline \multirow{3}{*}{$\begin{array}{l}\text { IQF peeled } \\
\text { undeveined }\end{array}$} & $40-80$ & $2.3 \times 10^{1} \pm 1.3$ & $2.3 \times 10^{1} \pm 1.3$ & $2.1 \times 10^{1} \pm 1.8$ & N.D & N..D & \\
\hline & $80-120$ & $2.5 \times 10^{1} \pm 1.2$ & $2.6 \times 10^{1} \pm 1.1$ & $2.2 \times 10^{1} \pm 1.6$ & N.D & N..D & \\
\hline & & & & & & & $\left(0.8 \times 10^{1}\right)^{\mathrm{a}}$ \\
\hline \multirow{3}{*}{$\begin{array}{l}\text { IQF peeled } \\
\text { deveined }\end{array}$} & $40-80$ & $0.95 \times 10^{1} \pm 1.4$ & $0.9 \times 10^{1} \pm 1.1$ & $0.3 \times 10^{1} \pm 0.8$ & N.D & N..D & \\
\hline & $80-120$ & $2.4 \times 10^{1} \pm 1.6$ & $2.2 \times 10^{1} \pm 1.3$ & $0.8 \times 10^{1} \pm 1.3$ & N.D & N..D & \\
\hline & & & & & & & $\left(0.4 \times 10^{1}\right)^{\mathrm{a}}$ \\
\hline \multicolumn{2}{|c|}{ Total mean count of $S$. aureus } & $\left(1.53 \times 10^{1}\right)^{\mathrm{a}}$ & $\left(1.3 \times 10^{1}\right)^{\mathrm{a}}$ & $\left(0.9 \times 10^{1}\right)^{\mathrm{a}}$ & N.D & N.D & \\
\hline
\end{tabular}

* N.D $=$ Not detected.

LSD at $\mathrm{P}>0.05$ for:- Shrimp processing $=0.2994$, Shrimp size $=0.4853$, Shrimp type $=0.498$

\section{Coagulase active Staphylococci:}

It is known that noses and hands of food workers are the major source of Staphylococci contamination (Arguedin et al., 2010). Results in Table (6) show very low load of $S$. aureus in frozen shrimps after thawing, marinating and breading steps. Again this means weakness in an application of good personal hygiene during carrying out the above processes. The detected loads are very far from that stated for this type of bacteria in cooked shrimp $\left(10^{3}\right)$ by ICMSF (1986). Heating treatment used during frying and grilling of different types and sizes of breaded and marinated thawed shrimps kill this type of bacteria. Singh et al., (1987) found that cooked shrimps contained less than 50 most probable number $\left(\mathrm{MPN} / \mathrm{g}^{-1}\right)$ S. aureus. 


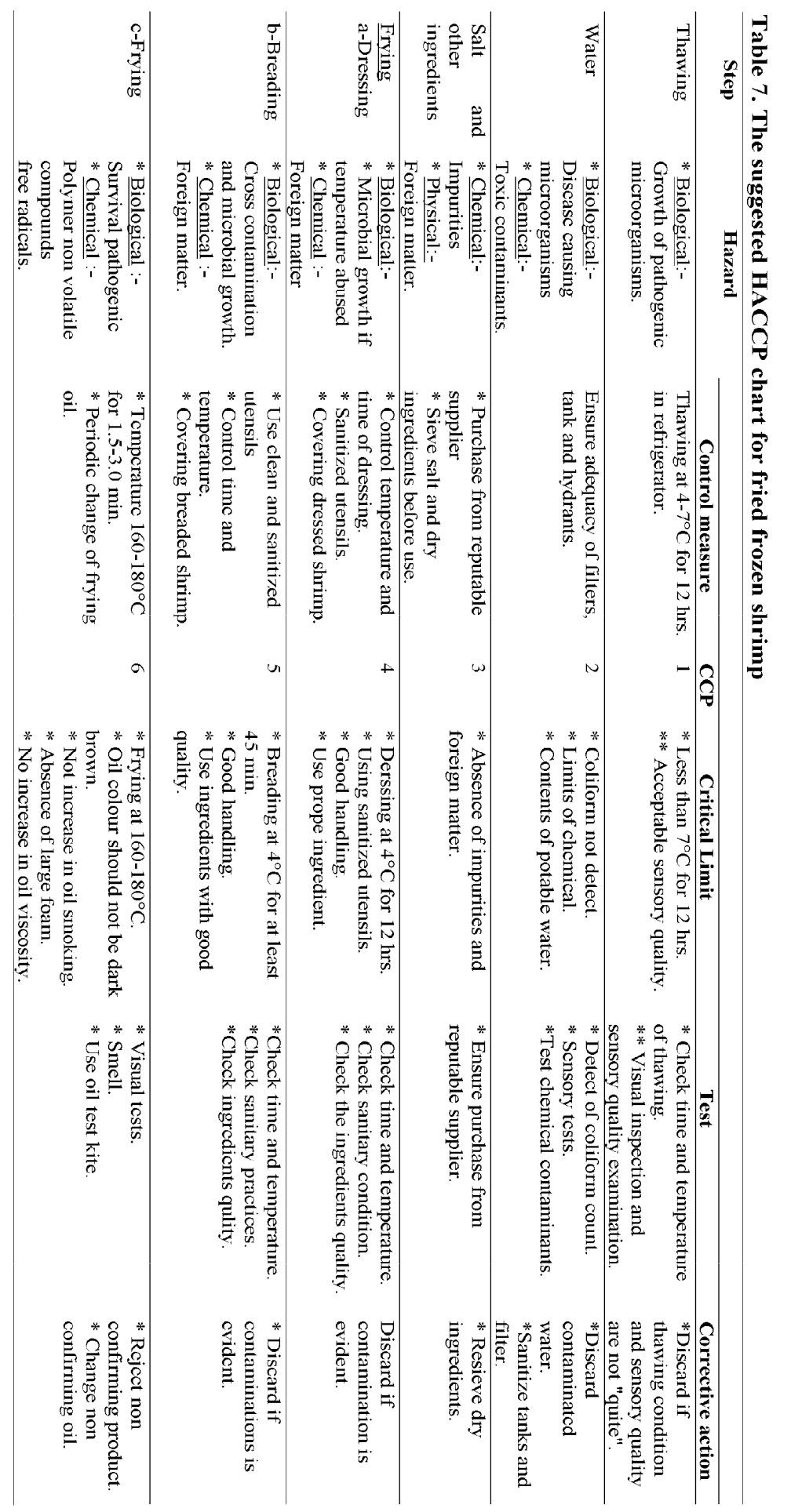




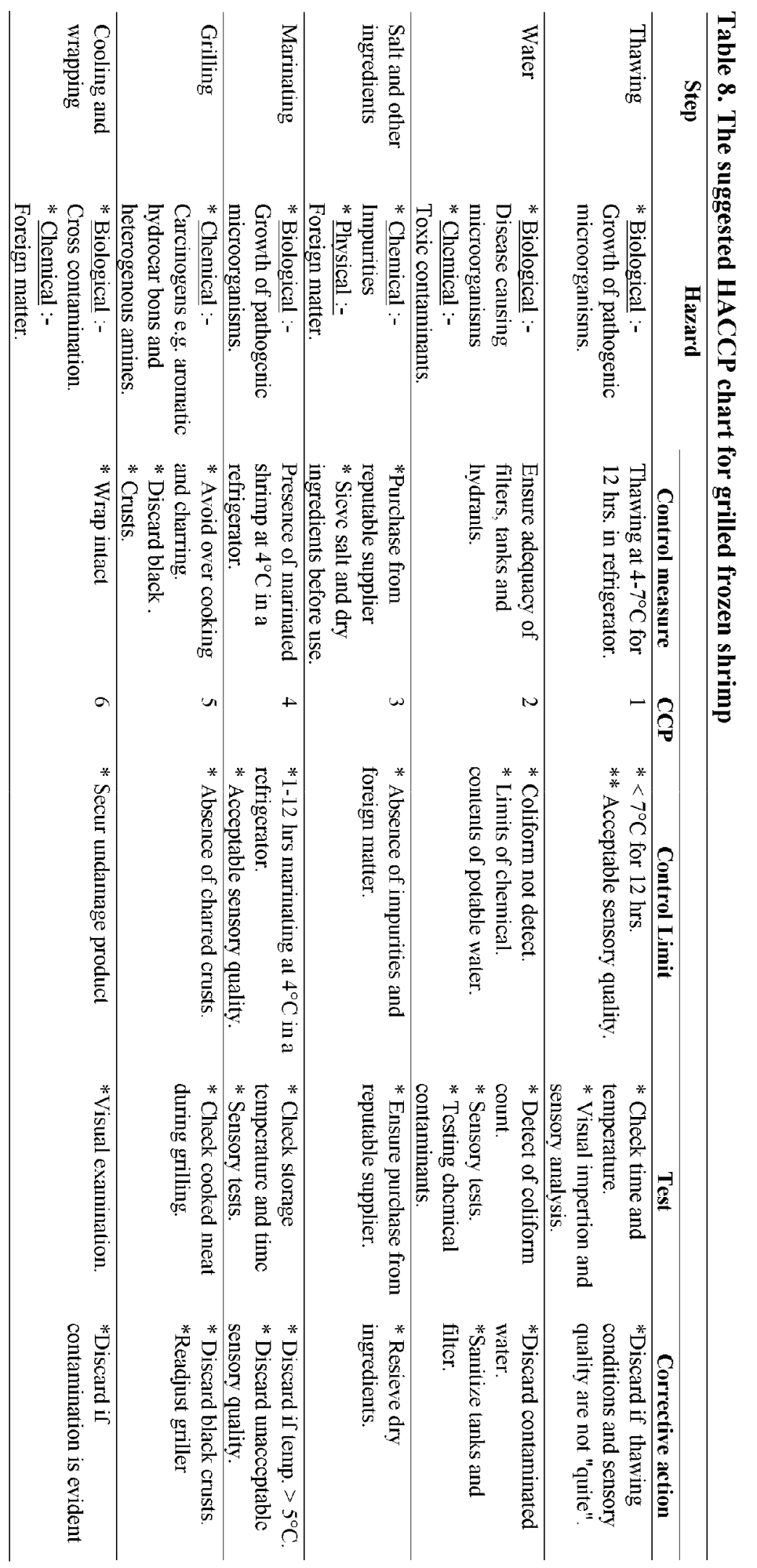




\section{CONCLUSION}

\section{The microbial hazards specific to cooked shrimp}

Products may be due to:- (a) improper preparation processes and cooking, (b) resultant in activations of microbial load, (c) possibility of high bacterial count in water, ingredients, food additives, (d) cross contamination during handling, processing, cooling, packaging, storage and (e) The absences of hygienic practices.

Tables (7) and (8) Summarized the suggested Hazard Analysis Critical Control Points (HACCP) charts for fried and grilled frozen shrimp products as recommended from the application of this research.

\section{REFERENCES}

AOAC. 2000. Official Methods of Analysis $\left(17^{\text {th }}\right)$. Association of Official Analytical Chemists. Gaithersburg, Maryland.

Arguedin,M.A., Mendoza, M.C., and Rodicio,M.R. 2010. Food poisoning and Staphylococcus aureus enterotoxins. Toxins, 2: 1751-1773.

Chen,H.C., M.W.Moddy, and S.Jiang. 1990. Changes in biochemical and bacteriological quality of grass prawn during transportation by icing and oxygenating. J. Food Sci., 55: 670-672.

Downes,P.E., and K.Ito. 2001. Compendium of Methods for the Microbiological Examination of Foods. American. Public Health Association, Washington, DC. pp. 25-35.

Fall,P.A., M.F., Pilet, F. Leduc, M.Cardinal, G. Duflos, C. Guerin, J.F.Joffraud, and F. Leroi. 2012. Sensory and physiochemical evolution of tropical cooked peeled shrimp inoculated by Brothothrix thermosphacta and Lactococcus piscium CNCM1-4031 during storage at $8^{\circ} \mathrm{C}$. International Journal of Food Microbiology, 152: 82-90.

Food and Drugs Administration (FDA). 2003. Quantitative assessment of the relative risk to public health from food borne Listeria monoctytogenes among selected categories of ready to eat foods. Available at: htt://www food safety.gov/-dms/1mr2-toc.html.Accesed: October 2009.

Gardio,V., A.L.Vitas, and I.Garcia-Jalon. 2009. Survey of Listeria monocytogenes in ready to eat products: Prevalence by brands and retail establishments for exposure assessment of Listeriosis in Northern Spain. Food Control. 20, 986-991.

Gonzalez-Fandes,E., A.Villarino-Rodriguez, M.C.GarciaLinares, M.T.GarciaArias, and M.C.Garcia-Fernandez., 2005. Microbiological safety and sensory characteristics of Salmon slices processed by Sous vide method. Food Control. 16: $77-85$.

Gram,L. and H.H. Huss. 1996. Microbiological spoilage of fish and fish products. International Journal of Food Microbiology. 33, 121-127.
He Wang, Ruijin Yang, Yanning Liu, Weibin Zhang, Wei Zhao, Yanpeng Zhong and Xiao Hua. 2010. Effect of low dose gamma irradiation on microbial inactivation and physico chemical properties of fried shrimp (Panaeus vannamai). International Journal of Food Science and Technology. 45: 1088-1096.

Ian-Dore and Claus-Frimodt. 1987. An Illustrated Guide to Shrimp of the World. Osprey Books, Huntigton, USA.

International Commission on Microbiological Specification for Food (ICMSF). 1986 Microorganisms in Food II. Toronto, Canada, University of Toranto Press.

International Commission on Microbiological Specification for Foods (ICMSF). 1978. Microorganisms in Food., 4. Application of Hazard Analysis Critical Control Point (HACCP), System to Ensure Microbiological Safety and Quality,Black Well Scientific Publication Oxford, London, U.K.

Jeyasekaran,G., P.Ganesan, R.Anandaraj, R.Jeyashakila, and D.Sukumar. 2006. Quantitative and qualitative studies on the bacteriological quality of Indian white shrimp (Panaeus indicus) stored in dry ice. Food Microbiology. 23, 526-533.

Kanduri,L. and R.A.Eckhardt. 2002. Food Safety in Shrimp Processing. A Handbook for Shrimp Processors, Importers, Exporters and Retailers. Fishing New Book; An imprim of Black Well Science, New York, USA.

Larke,P., and L.Farber.1971. Heat pasteurization of crab and shrimp from pacific coast of United States, Public health aspects. J. Food Science, 36: 277-279.

Miget, R.J. 1991. Microbiology of Crustacean Processing, Shrimp, Craw Fish and Prawns In: "Microbiology of Marine Food Products". World, D.R. and Hackney,C. (Eds). An-avi. Book, Van Nostrand Reinhold Publisher, New York, pp: 65-87.

Mohamed Hatha, A.A., T.K.Magbool, and S.Suresh Kumor. 2003. Microbial quality of shrimp products of export trade produced from aqua cultured shrimp. International Journal of Food Microbiology, 82: 213-221.

Moharram,Y.G. and H.M.Al-Kodaby. 2015. Food Safety Management in Food Processing Units. In Second Arab Proceeding on Food and Drugs, Present Challenges and Future Requirements. pp. 49-50. Organized by the Arab Administrative Development Organization League of Arab States, Ministry of Health and Population, Arab Republic Egypt and the Executive Board of Health Ministers Council for GCC State, In Sharm El-Sheikh, Arab Republic Egypt, 11-13 April.

Norrung,B. and S.Buncic. 2008. Microbial safety of meat in the European Union. Meat Science, 78: 14-24.

Oosterveer,P. 2006. Globalization and sustainable consumption of shrimp: Consumers and governance in the global space of flows. International Journal of Consumer Studies, 30: 465-476. 
Oxoid. 2002.Tryptone bil X-glucronide medium (TBX); A selective chromogenic media for the detection and enumeration of $E$. coli in Food. http:///www oxoidcom./UK/index.asp?mpage=ipreductetail\&pre=CM0945\& $1=\mathrm{EN} \& \mathrm{x}$.

Patricia-Anacleto, Barbara Teixeira, Pedro Marques, Sonia Pedro, Maria Leonor Nunes and Antonio Marques. 2011. Shelf life of cooked edible crab (Cancer pagurus) stored under refrigerated conditions. LWT-Food Science and Technology, 44, 1376-1382.

Perez-Rodriguez,F., R.Castro, G.D.Posada-Izquierdo, A.Valero, E.Carraso, R.M.Garcia-Gimeno, and G.Zurera. 2010. Evaluation of hygiene practices and microbiological quality of cooked meat products durng slicing, and handling at retail. Meat Science, 86: 479-485.
Sedaroglu,M., K.Abdraimov, and A.Onence. 2007. The effect of marinating with citric solution and grape fruit on cooking quality of Turkey breast. J. Muscle Food., 18: 162-172.

Singh,D., M.Chan, H.Heen Ng, and M.D.Yong. 1987. Microbiological quality of frozen raw and cooked shrimps. Food Microbiology, 4, 221-230.

The Egyptian Organization for Standardization and Quality Control. 2005. Egyptian Standard of Specification of Frozen Shrimp. No. 516-Ministry of Industry and Technological Development, Cairo, Egypt.

Valdimarsson, G., H.Einarsson, B. Gudbjornsdottir, and H.Magnusson. 1998. Microbiological quality of Icelandic cooked peeled shrimp (Pandalus borealis). International Journal of Food Microbiology, 45: 157-161.

\section{الملضص العري \\ الضرار الميكروية الثناء التحمير وشي الجمبري المجمد (Panaeus spp) \\ ناية لحمد عبد العزيز، يحيه جمل الينمحرم}

Staphylococcus العد لكل من بكتري L ابكتري L coliform

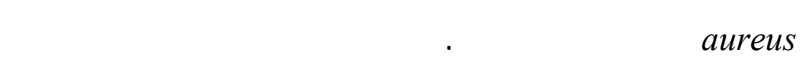

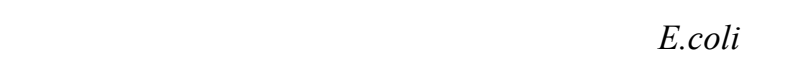

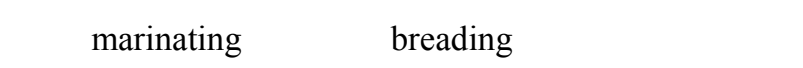

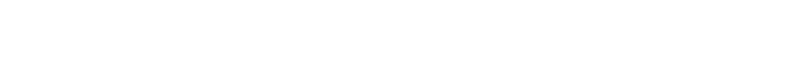

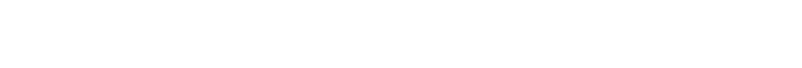

واللشترطك الصحية المتبعة خلل إعداد وطبخ الجمب -ري

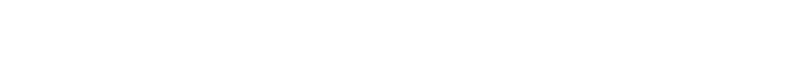

ظله تحليل المخطلر وقطل ال تحكم الحرج ـة (الهلب دب)

لتحمير وشي الجمبري المجمد.
مُ في هذه الدرلس ـةالتعرف عل م الاض _رار خاص ـة

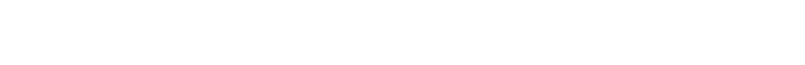

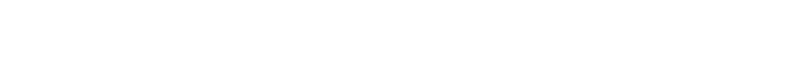
التحمير وللثي. ووجد من التحلي لل الاح مصائي للنت ائج

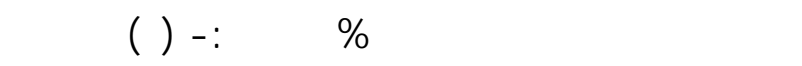

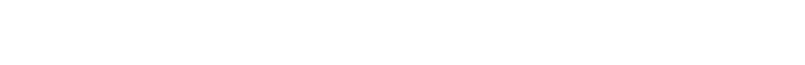

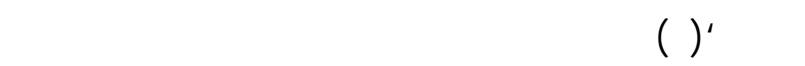

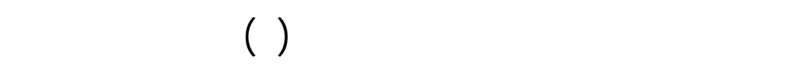

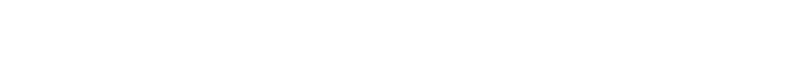
من الميكروبات، (ع) النوع وطريقة الطبخ والتدلخل بينهما

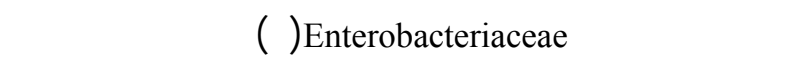

